\title{
The Social Construction of Entrepreneurship in the Minangkabau Millennial Generation
}

\author{
Damsar $^{1}$, Indrayani ${ }^{2}$ \\ $\left\{{ }^{1}\right.$ damsar@soc.unand.ac.id 2yaniindra@gmail.com $\}$ \\ ${ }^{1}$ Universitas Andalas, Padang, Indonesia \\ ${ }^{2}$ Universitas Batam, Batam, Indonesia
}

\begin{abstract}
The internet has changed many aspects of human life. The internet has also affected the economic life of the community, including influencing entrepreneurial construction in society. In this regard, it is interesting to find answers to how the process of social construction of entrepreneurship occurs in the generation exposed or affected by the internet, namely the millennial generation. To get answers to these questions, a study was conducted with a qualitative approach. Data was obtained through in-depth interviews with 20 people from the millennial generation involved in a business based on social media. In addition, observations were also made of the business activities of the millennial generation on social media. Data analysis was performed using the Miles and Huberman models. The results of the study show that entrepreneurship from the millennial generation is socially constructed dialectically between traditional social institutions, family, overseas realities, and social media.
\end{abstract}

Keywords: Entrepreneurship, Social Construction, Millennial Generation

\section{INTRODUCTION}

Based on Internet World Stats reports about internet users in the top 20 countries as of March 31, 2019, Indonesia is ranked 5th as the largest internet user in the world. When referring to the statistics of internet users from the Indonesian Internet Service Provider Association (APJII) in 2017 [1], of a population of around 262 million there are around 143.3 million internet users. Thus there is around $54.68 \%$ of Indonesia's population exposed to the internet. Of these, it turns out that the biggest internet users in Indonesia are those aged 19-34 years, namely $49.52 \%$ and followed by ages $35-54$ years, which is $29.55 \%$ and followed by the age group 13-18 years, which is equal to $16.68 \%$.

Based on the results of a survey conducted by APJII in 2017, it turns out that the dominant age group using the internet is a group of people born between 1985 and 2000. Birth groups at that time period are known as the millennial generation or generation Y [2]. The birth span of the millennial generation was set differently by various experts, such as Ensari [3], between 1980 and 1995, Ball \& Gotsill [4], namely between 1983 and 1997, and Twenge et al. [5], namely between 1982 and 1999. So, there is no definite time limit for the beginning and end of this group. Experts and researchers usually use the early 1980s as the beginning of the year of birth of this group and the mid-1990s to the early 2000s as the end of the year of birth. 
Thus the millennial generation is the first generation most exposed to the internet. That means that the millennial generation is a generation where many aspects of their lives are influenced by the internet. This is consistent with the opinion of many experts that the internet has influenced many aspects of human life [6], [7], such as communication [8]-[11], culture [12], social [13]-[15], and politics [16], [17]. The internet has also affected the economic life of society [18], [19], including the influence on entrepreneurship [20]-[23]. The experts' views are in line with the characteristics of the millennial generation described as a digital generation or generation accustomed to internet technology, as individuals who "like informality," "respect diversity," "free to act," and "learn quickly", [3], [5], [24]-[27].

Related to this, it is interesting to see whether the characteristics of the millennial generation as stated above are also shared by the Minangkabau millennial generation? The Minangkabau people are known in Indonesia because they are widely involved in various economic and business activities [28]. Therefore, they are seen as a community that has a high entrepreneurial spirit in Indonesia [29]. Indeed, many experts have conducted research on entrepreneurship from Minangkabau people such as Yolanda's study of cultural values in business behavior [30], Games et al study of interrelationships between entrepreneurship and religious and customary values, Poespowidjojo et al about entrepreneurship and culture of solidarity [31], and Hastutia et al about the entrepreneurial characteristics of the Minangkabau ethnic group [32]. However, research on entrepreneurship from the Minangkabau millennial generation has never been done. Based on the reality of the research on entrepreneurship in the Minangkabau community, therefore, it is interesting to see how the social construction of entrepreneurship in the Minangkabau millennial generation?

\section{RESEARCH METHOD}

To answer the question of how entrepreneurship is socially constructed in the Millennial Minangkabau generation?, then a qualitative study was conducted of 20 informants in Padang, Pekanbaru and Jakarta. The informants were selected purposively, with criteria including: (1) they were Minangkabau people, (2) have birth years between 1980 and 2005, (3) have business independently, and (4) use social media. Data obtained by conducting in-depth interviews and observations. In-depth interviews are conducted through social media. While observations are made on the use of social media by informants and the reality of traditional social institutions such as lapau, surau and tapian. Triangulating the source and performing triangulating techniques were used for data validation. Miles and Huberman models were used to analyze data.

\section{RESULTS AND DISCUSSION}

\subsection{Diversity of Minangkabau Millennial Generations}

Although the millennial generation of Minangkabau in general has similarities, namely they are very familiar in the use of communication, media, and digital technology, it turns out that they have differences in the process of forming an entrepreneurial spirit. This occurs because of differences in the background of the area of origin, year of birth, and education. Therefore, the diversity of the generation of Minangkabau millennia needs to be discussed first before discussing how their entrepreneurship is socially constructed.

The millennial generation cohort covering the time from the 1980 s to the early 2000 s was a long period of time. Many social, cultural, political, and economic events that occur during 
this period of time. The diversity of these events has provided a different experience in the social construction of entrepreneurship in the Minangkabau millennium generation. In the 1980s, Indonesia's economy experienced very good growth among developing countries, which was in the range of $7 \%$. The economic climate is very directed, with the aim of advancing agriculture and industry. In that decade, people tended to prefer to build ordinary houses compared to the rumah gadang (the big houses).

In 1998 Indonesia experienced an economic crisis which caused economic growth to decline to minus $13.13 \%$. This situation led to the collapse of the New Order's authoritarian regime. Since the collapse, freedom of expression and articulation have become very open.

Meanwhile, in the 1980s there was also the development of information technology that connected many Indonesians through mailing list-based internet networks. Starting from around 1987-1988, a small group of Indonesian students in Berkeley, the United States formed the first Indonesian mailing list with an e-mail address indonesians@janus.berkeley.edu. The community of Indonesian students and students abroad is formed with the existence of this virtual discussion facility. This community develops the is-lam@isnet.org mailing list, paroki@paroki.org, and others. Whereas in Indonesia alone, mailing lists were formed since the return of students who had finished their studies abroad, which was around 1993-1994. The rapid growth of mailing-based internet communities in Indonesia was driven by the Bandung Institute of Technology (ITB) in 1995-1997. Minangkabau was formed by the Minangkabau community abroad in 1993 and in 1994 having the address rantaunet@rantau.stanford.edu. The existence of this mailing list provides a locus for freedom of expression and issue opinions and strengthen awareness about diversity.

The existence of social networking media in the world began with the emergence of Friendster in 2002 which is an application to build relationships of cyberspace friendships. Then in 2003 the MySpace and LinkedIn sites were established. In 2004 Flickr and Facebook emerged as newcomers to social media. Then in 2006 the new networking site emerged namely Twitter. Next, in 2009 and 2010, WhatsApp and Instagram were released sequentially. In 2011 Line and Snapchat emerged as social networking sites.

The diversity of the Minangkabau millennial generation can be divided based on the technological, social, cultural, political and economic changes that occur. The milestones of information technology change are the entry and development of the internet in Indonesia through the movement of internet-based mailing list development by ITB in 1995. As well as the milestones of social, cultural, political and economic changes in 1998, known as the economic crisis and reform. These two changes are fair between the two Minangkabau millennial generations, namely the early millennial Minangkabau generation, namely the Minangkabau generation born from 1980 to 1995, and the late Minangkabau millennial generation, namely the Minangkabau generation born in 1996 to 2005.

The life philosophy of the Minangkabau people, namely "the nature unfurled becomes a teacher" (alam takambang jadi guru), becomes a source of value for entrepreneurship. Minangkabau entrepreneurial values such as self-assurance, hard work, careful computation, independent, diligent, contribution to the family, consistent, clever, flexible, courageous to do business along with challenges [32] are transmitted through traditional institutions such as community bathing place (tapian), coffee shop (lapau), prayer place (surau), and traditional art performances [33].

The traditional institution communicates various events that occur in the community and disseminates various values of life, including entrepreneurial values, to community members involved in the institution. Young members receive stories about life experiences along with 
the life values contained in them from adults or parents from the community through these traditional institutions.

The early millennial Minangkabau generation experienced how these traditional institutions transmitted various life experiences and entrepreneurial values possessed by adults or parents of their community. On the other hand, for the late millennial Minangkabau generation did not receive the experience of socialization as experienced by the early millennium Minangkabau generation. That is due to the occurrence of economic growth, which has led to the tendency of people to build ordinary houses compared to big houses (rumah gadang). A regular house has a bathroom so people don't need to go to the community bath anymore. In addition, almost every regular home has a television, so people no longer need to go to a coffee shop to get information or to the traditional art performances to get entertainment. So the role of traditional institutions in transmitting entrepreneurial values has faded during the late millennial Minangkabau generation.

\subsection{The Declining of the Minangkabau Extended Family}

The big house is the base of Minangkabau extended family. The big house is traditionally inhabited by all members of the extended family, which drawn through the mother's line (matriliny). The big house, therefore, can be inhabited by family members from 3 different generations. In a situation like this, young members of a extended family grow. All adult members of the big house educated and socialized the values and norms adopted by the family, namely adat and Islam [33]. In a family like this, the father does not make an important contribution to his children. The father's role in providing education and teaching to children in the big house was taken over by their mother's brother, known as "mamak". Early milleneal Minangkabau generations were educated and socialized by extended families at the big house.

Unlike the early milleneal Minangkabau generation that most of them lived in big houses, most of the late millennial Minangkabau generation lived in ordinary homes, where only mothers, fathers and unmarried children lived together in it. Parents, including fathers, play an important role in education and transfer values and norms to all their children in the ordinary house. If there are older children in the house, they will also transfer important values from the family to younger family members. When their ordinary house is located within their extended family environment, adult members of their extended family also contribute to education and socialization of values and norms. Even so, the role of the father remains dominant in the nuclear family.

The declining of the role of the extended family in Minangkabau society is caused by various factors, namely: one, the weakening of the economic base of the extended family in the form of rice fields and leas. Population increase causes the need for land to increase. Meanwhile, the area of land has never increased. As a result, the limited land cannot support the extended family. Two, the strengthening of father's economic role in supporting family life. Three, the strengthening of the understanding of Islam about the obligations of fathers in the family economy and the education of their children. Four, the diminishing role of brothers from mothers (mamak) in the extended family economy, because they have an obligation to support their nuclear families. 


\subsection{Merantau}

The existence of Minangkabau people in various markets, both modern and traditional, in all regions of Indonesia is inseparable from the influence of the institution "merantau" to the Minangkabau people. Merantau is a migration pattern of Minangkabau people who build in their culture, which encourages them to leave their hometowns to gain knowledge, experience, or prosperity in the overseas, so that later they will be useful in their hometowns. Merantau, therefore, is the cultural mission of the Minangkabau people to develop themselves into an entrepreneur in various fields according to Minangkabau custom and Islamic teachings [34] [36].

Merantau is a socio-cultural practice of Minangkabau people on the cultural mission that is carried out and the social reality they are facing in their daily lives. The values and teachings of adat and Islam, including the value of entrepreneurship internalized by the community and family, have a locus for practice in the real world through merantu. Entrepreneurial practice involves the formation of social networks and trust [31], [34].

The formation of social networks in social construction on entrepreneurship takes various sources from the network. A migrant, from both the early and the late millennial Minangkabau generation, usually uses matrilineal social networks and similarities in the Minangkabau locality. The social network based on Minangkabau matrilineal kinship includes "samande" (the same mother), "saparuik" (the grandmother same), "sanenek" (the same greatgrandmother), "saninik" (the same mother of one's great-grandmother), "sakaum" (the same sub-clan), and sasuku (the same clan). Whereas social networks are based on similarities in the Minangkabau locality include sanagari (the same village), saluhak (the same region), and saminangkabau (from the Minangkabau area). Migrants who go to Jakarta or Pekanbaru usually use social networks on the basis of the Minangkabau matrilineal kinship. If they do not have the network, then they use a Minangkabau locality-based network. If they do not have both networks, the alumni network (school or college) can be used. The strong weak social network that binds a person in the social construction of entrepreneurship depends on the dynamics of the history of social relations with the basis of the network formed. One of the most important factors that influence the strength of social networks is trust.

Trust grows, develops, survives, diminishes, or even disappears in a social relationship [37]-[39]. Trust, for that reason, has a dynamic, which is the result of a social construction [40]-[42]. Values about honesty and trustworthiness that come from adat and religion can be a guideline and guidance for people in forming a trust. Migrants already have a trust that is still basic through their own social networks. Trust that is still basic in nature can grow or vice versa can be lost. This depends on how they manage honesty and trustworthiness, which are internalized through adat and Islam, towards the trust given to them. A person's success in business depends on managing honesty and trustworthiness in the trust given and the ability to see business opportunities. Trusts will increase along with the increase in performance towards honesty and trustworthiness. Instead the trust will decrease even disappear if the reduction in performance towards honesty and trustworthiness.

The social network owned by the millennial Minangkabau generation is used as a place of internship to obtain various abilities, skills, knowledges, informations and business networks. If migrants feel they have all these things, then they will open a similar business in another location or different from where they work. The initial investment capital can be in the form of loans or profit sharing from the patron, namely the social network on which they conduct an internship. But some of the other initial investment capital comes from their nuclear family. 


\subsection{Social Media}

The early millennial Minangkabau generation first came into contact with social media through mailing lists, namely @ rantaunet. After that developed various types of nagari, district, alumni of schools and universities-based mailing lists. The mailing list is used by users for various purposes such as friendship, exchange of information, social networks, or business. The mailing list has faded its role as social media when various more interactive social media appear with various features with various functions such as Facebook, Twitter, Instagram, WhatsApp, and Line. This generation has developed independent businesses when social media began to develop. When online businesses flourish, they begin to enter ecommerce through social media, especially Facebook and Twitter. In addition, some of them have developed their business ventures into marketpalces such as Bukalapak, Tokopedia, and Shopee. They also use LinkedIn, Twitter, Instagram, WhatsApp and Line to add networks.

Whereas the late millennial Minangkabau generation did not feel how the discussion developed in the mailing list. They can feel how to network through Facebook, Twitter, LinkedIn, Instagram, WhatsApp, Snapchat and Line. This generation is not just networking but getting learning and knowledge about how people do business through social media. Some of them get inspiration and encouragement to do business through their interaction with social media. Also some of them started doing business independently through social media. The social media that they often use to do business is Facebook, Instagram and WhatsApp group. They also use WhatsApp and Line to have conversations with consumers. Social media, thus, is not only a medium of communication and social networking but also as an agent of socialization in entrepreneurship and at the same time as a place of practice of what has been internalized.

Social media has filled the space left by traditional social institutions in socializing entrepreneurship to the Minangkabau millennial generation. Nagari-based WhatsApp group, for example, has provided a variety of values, knowledge, and strategies in business. WhatsApp group has become a new network that unites the hometown (kampung halaman) and overseas (rantau). There are only members of the WhatsApp community who share their experiences and strategies in doing business in the social media. The use of social media like this is also the basis of the development of social capital of community members.

\subsection{Social Construction of Entrepreneurship}

Values of adat and Islam internalized through traditional social institutions and families settle down as a subjective reality possessed by the millennial Minangkabau generation. This subjective reality was also formed by the internalization of the success stories of the migrants who were returning homeland. The subjective reality will be dialectic with the reality of their experience when migrating (merantau).

Social media becomes both a subjective reality and an objective reality. As objective reality, social media is a social fact that influences the way of acting, feeling and thinking of the millennial generation. The Social fact is internalized through imitation, copying, modification, and doing. In this way the objective reality is a part of subjective reality for the millennial generation, especially the late millennial Minangkabau generation.

Entrepreneurship always develops along with the objective reality experienced by actors, both the early and the late millennial Minangkabau generation, such as the development of information technology, overseas conditions, and social capital owned. This objective reality becomes a subjective reality through interpretation, communication, and interaction between 
various related actors in business [43]. Because of the entrepreneurial experience between the early and the late of the millennial Minangkabau generation is different.

\section{CONCLUSIONS}

The millennial Minangkabau generation have differences between each other. These differences are based on the different objective realities they face such as the reality of traditional social institutions, the socio-political development of the community, the development of information technology, different overseas realities, and the development of existing social capital. Entrepreneurship from the early of the millennial Minangkabau generation is socially constructed in a dialectic between traditional social institutions, families, and overseas realities. While entrepreneurship from the late of the millennial Minangkabau generation is socially constructed in the dialectic between family institutions, social media and overseas realities.

\section{REFERENCES}

[1] APJII (Indonesia association internet services organizer) Report on 2017. [Online]. Available: https://apjii.or.id/survei.

[2] L.G. Shiffman and L.L. Kanuk, Consumer Behavior. Upper Saddle River, New Jersey: Pearson Education/Prentice Hall, 2010.

[3] M. S. Ensari, "A Study on the differences of entrepreneurship potential among generations," RJBM, vol. 4, no. 1, pp. 52-62, 2017.

[4] K. Ball and G. Gotsill, Surviving the Baby Boomer Exodus : Capturing Knowledge for Gen $X$ and Gen $Y$ employees. Boston, Mass : Course Technology PTR, a part of Cengage Learning, 2011.

[5] J. M. Twenge, S. M. Campbell, B. J. Hoffman \& C. E. Lance, "Generational differences in work values: Leisure and extrinsic values increasing, social and intrinsic values decreasing," JoM, vol. 36, no. 5, pp. 1117-1142, 2010.

[6] B. Sutton, "The Effects of Technology in Society and Education," Education and Human Development Master's Theses, 2013. [Online]. Available: http://digitalcommons.brockport.edu/ehd_theses/192.

[7] B. Wellman and C. Haythornthwaite, Eds., The Internet in Everyday Life. Oxford, UK: Blackwell Publishing, 2002.

[8] T. W. Brignall and T. Van Valey, "The impact of Internet communications on social interaction," Sociol. Spec., vol. 25, no. 3, pp. 335-348, 2005.

[9] M. Castells, The Rise of the Network Society. Malden, MA: Blackwell Publishing, 2000.

[10] N. H. Nie and D. S. Hillygus, "The impact of Internet use on sociability: Time-diary findings," IT \& Soc., vol. 1, no. 1, pp. 1-20, 2002.

[11] G. Pronovost, “The Internet and time displacement: A Canadian perspective," IT \& Soc., vol. 1, no. 1, pp. , pp. 44-53, 2002.

[12] J. A. Bargh, "Beyond simple truths: the human-Internet interaction," J. Soc. Issues, vol. 58, no. 1, pp. 1-8, 2002.

[13] J. N. Cummings, B. Butler \& R. Kraut, "The quality of online social relationships," 
Com. ACM, vol. 45, no. 7, pp. 103-8, 2002.

[14] P. DiMaggio, E. Hargittai, W. R. Neuman \& J. P. Robinson, "Social implications of the internet," Annu. Rev. Sociol., vol. 27, pp. 307-36, 2001.

[15] C. Keser, J. Leland, J. Shachat \& H. Huang, "Trust, the Internet, and the Digital Divide,” IBM Sys. J., vol. 42, no. 3, pp. 507-18, 2003.

[16] H. Farrell, "The Consequences of the internet for politics," Annu. Rev. Polit. Sci., vol. 15. pp. 35-52, 2012.

[17] B. A. Bimber, "The Internet and political transformation: populism, community, and accelerated pluralism," Polity, vol. 31. Pp. 133-60, 1998.

[18] S. Y. Chu, "Internet, economic growth and recession," J. Modern Econ., vol. 4, pp. 209-13, 2013.

[19] R. Jensen, "The Digital provide: information (technology), market performance, and welfare in the South Indian Fisheries Sector," Quart. J. Econ., vol. 122, no. 3, pp. 879924, 2007.

[20] Y. C. Ojeleye, M. I. Opusunju, A. I. Ahmed \& S. Aku, "Impact of social media on entrepreneurship among users in Zamfara State," J. Econ. Fin., vol. 2, no. 2, pp. 303-26, 2018.

[21] Z. Mahwish, S. Wajahat, K. Shazia, Q. Y. Hummaira \& N. Nadia, "Impact of social media on entrepreneurship growth: a case of Lahore, Pakistan," IJESRT, vol. 6, no. 1, pp. 387-94, 2017.

[22] V. Balachandran and M. S. Sakthivelan, "Impact of information technology on entrepreneurship," JBM \& SSR, vol. 2, no. 2, pp. 51-56, 2013.

[23] J. Ambrose and C. Kinyua, "The Social media and entrepreneurship growth (a new business communication paradigm among SMEs in Nairobi)," IJHSS, vol. 3, no. 10, pp. 213-27, 2013.

[24] P. Khor, "A Phenomenological study of the lived experiences of the generation $\mathrm{X}$ and $\mathrm{Y}$ entrepreneurs," SINERGI, vol. 7, no. 2, pp. 16-24, 2017.

[25] J.C. Hansen and M. E. Leuty, "Work values across generations," J. Career Ass., vol. 20, no. 1, pp. 34-52, 2012.

[26] C. C. Shih, The Facebook Era. Tapping Online Social Networks to Build Better Products, Reach New Audiences, and Sell More Stuff. Boston: Prentice Hall, 2009.

[27] V. I. Sessa, R. I. Kabacoff, J. Deal \& H. Brown, "Generational differences in leader values and leadership behaviors," Psy. Manag. J., vol.10, no. 1, pp. 47-74, 2007.

[28] Damsar, "Konstruksi sosial budaya Minangkabau atas pasar," J. Ant., vol.18, no.1, pp. 29-38, 2016.

[29] I. Manan, "Impacts Of Development On Entrepreneurship And Minangkabau Enterprise," in Socio-Cultural Impacts of Development: Voice The Field. Padang: Andalas University Research Center, Padang, 1990.

[30] N. Yulanda," Pengaruh Nilai Budaya Bisnis pada Masyarakat Minangkabau terhadap Perilaku Kewirausahaan Pedagang Perantau di Tanah Abang," S2 Thesis, Universitas Pendidikan Indonesia, 2012.

[31] D. A. L. Poespowidjojo, M. N. Mohd Shariff, M. M. and Muhaizam, "Solidarity Factor in Cultivating Entrepreneurial Culture among the Minangkabau's Sub-Ethnic 
Group, West Sumatera, Indonesia," in The 2nd International Conference on Rural Development and Entrepreneurship (ICORE), 2013.

[32] P. C. Hastutia, A. Thoyibb, E. A. Troenac and M. Setiawan,'The Minang entrepreneur characteristic," in The 2nd Global Conference on Business and Social Science $\quad$ (GCBSS), $2015 . \quad$ [Online]. Available: https://www.sciencedirect.com/science/article/pii/S1877042815054488.

[33] Damsar and Indrayani, "Local Wisdom Based Disaster Education in Minangkabau Society," in The International Conference on Disaster Management (ICDM), 2018. [Online]. Available: https://doi.org/10.1051/matecconf/201822904017.

[34] H. Rahman, “'Merantau' - An Informal Entrepreneurial Learning Pattern in the Culture of Minangkabau Tribe in Indonesia," in DeReMa J. Manaj., vol. 11, no. 1, pp. 15-34, 2016.

[35] U. Pelly, Urbanisasi dan Adaptasi: Peranan Misi Budaya Minangkabau dan Mandailing. Jakarta: LP3ES, 1994.

[36] M. Naim, Merantau Pola Migrasi Suku Minangkabau. Yogyakarta: Gajah Mada University Press, 1979.

[37] Damsar and Indrayani, Pengantar Sosiologi Pasar. Jakarta: Prenadamedia, 2018.

[38] Damsar and Indrayani, Pengantar Sosiologi Kapital. Jakarta: Prenadamedia, 2019.

[39] R. M. Z. Lawang, Kapital Sosial dalam Perspektif Sosiologi, Suatu Pengantar. Depok: FISIP UI Press, 2004.

[40] P. L. Berger, and T. Luckmann, Tafsir Sosial Atas Kenyataan, Risalah tentang Sosiologi Pengetahuan (trans.). Jakarta: LP3ES, 1990.

[41] Damsar and Indrayani, "Social Construction of Trust in the Investment of "Bodong", in the International Conference on Business and Management Research (ICBMR), 2017. [Online]. Available: https://doi.org/10.2991/icbmr-17.2017.22.

[42] Damsar and Indrayani, Pengantar Sosiologi Ekonomi. Jakarta: Prenadamedia, 2015.

[43] K. Saddhono, S. T, Widodo, M. T. Al Makmun, and M. Tozu, "The study of philosophical meaning of batik and kimono motifs to foster collaborative creative industry." Asian Soc. Sci. vol. 10 no. 9 pp 52-61, 2014 